\title{
Southeast Asian low-cost carrier airline competitiveness: A solution for economic growth
}

\author{
Phoom Srisook, Vinai Panjakajornsak \\ Faculty of Administrative and Management \\ King Mongkut's Institutes of Technology Ladkrabang, Thailand
}

corresponding e-mail: phoomsrisookkmitl[at]gmail(dot)com

address: King Mongkut's Institute of Technology Ladkrabang (KMITL), AMC Research Center, Prathep Building \# 2, Second Floor, 1 Chalong Krung, Thanon Chalong Krung, Lat Krabang, Bangkok 10520

\begin{abstract}
:
In 2016, low-cost carrier (LCC) passengers represented 53\% of the all airline passengers in Southeast Asia, with new aircraft deliveries in 2017 expected to increase by 11\%. In Thailand, LCCs in 2016 represented $44.9 \%$ of all passengers through Thailand's 6 major airports, which represented 54.7 million passengers out of a total of 122 million air travelers. Competition however amongst the LCCs has become fierce, with fare reductions being a common tactic to fill seats. This study, therefore, developed a questionnaire which included 58 items on passenger characteristics, the LCC service marketing mix, service quality, passenger expectations, and LCC competitiveness along with their 18 related observed variables. Multistage random sampling was employed to obtain 320 passenger respondents who were departing on either Thai AirAsia, Thai Lion Air, Thai Smile, or Nok Air from one of Bangkok's two main airports. Results determined that the service marketing mix plays the most important role in an LCC's competitiveness.
\end{abstract}

JEL Classifications: L25, L89, L93, N75, R49

Keywords: Aviation industry, competitive advantage, passenger expectations, service marketing mix, Thailand 4.0

Citation: Srisook, P., Panjakajornsak, V. (2017). Southeast Asian low-cost carrier airline competitiveness: A solution for economic growth. Business and Economic Horizons, 13(4), 536-555,

http://dx.doi.org/10.15208/beh.2017.37

\section{Introduction}

Low cost carriers (LCCs) came into existence within the Association of Southeast Asian Nations (ASEAN) after the 1997 global financial crisis. Many scholars agree that it was this crisis that had a significant impact on the introduction of the region's first LCC, Malaysia's AirAsia in 2001, and numerous aviation endeavors later on (Air Asia Annual Report, 2011; Tham, 2008).

Deregulation and the implementation of the ASEAN Single Aviation Market (ASAM or ASEAN Open Sky Agreement) have also contributed to the rise of LCCs in the region. Multiple studies have also confirmed that deregulation has changed the competitive nature of the aviation industry (Baker, 2013, 2014; Kim \& Lee, 2011; Smith \& Cox, 2008), especially as it has been applied to LCCs (Damuri \& Anas, 2005).

In the new environment any ASEAN member state airline could operate both passenger and cargo scheduled services between its home country and another member country's international airport (Grosso \& Shepherd, 2010). New agreements stipulate no limitations on capacity and schedule (ASEAN Briefing, 2015). The intent of ASEAN-SAM is, therefore, to provide no regulatory limits on the frequency or capacity of flights between 
international airports throughout the 10 ASEAN member community. This is consistent with Ishutkina \& Hansman (2009) who determined that the creation of LCCs often follows changes in the aviation regulatory framework; LCCs stimulate demand and significantly increase the traffic primarily due to lower fares. Furthermore, the introduction of domestic and/or international LCC services results in significant changes in the air passenger growth rates, both in developed and developing economies.

As a result of the 1997 Asian financial crisis, entrepreneurial opportunities arose in the form of low-cost airlines that helped meet the demand for financially strapped businessmen and leisure travelers (Corea, 1998; Ishutkina \& Hansman, 2009). One such endeavor which has endured is Thai AirAsia which began its journey in February 2004. From Air Asia's own 2011 financial report, it states that in this period, 'low-cost air travel was virtually unknown in Thailand', with air travel only for the elite who could afford the premium airfares (Air Asia Annual Report, 2011).

Subsequently, over the next four years, the Thai domestic market tripled from 4 million to more than 12 million passengers, with LCCs accounting for 8.5 million of the total (Sobie, 2008). By 2008, Singapore's Tiger Airways and Jetstar Asia were common names for budget travelers. Added to these were Thailand's Nok Air and One Two Go. Indonesia also added Awair and Lion Air to the region's list (Tham, 2008). Similarly, LCC development helped to stimulate domestic passenger growth in other countries during this period, such as Turkey, South Africa, and Indonesia.

In 2009-2013, ASEAN airlines experienced double-digit growth, while at the end of 2016 there were 23 ASEAN LCCs with a fleet of 623 aircrafts which expanded $50 \%$ in just three years (CAPA, 2016a; CAPA, 2017). Therefore, Thailand's domestic market has become a major battleground for these ASEAN LCCs; in 2014 it accounted for $35 \%$ of total passenger traffic in the Bangkok market (CAPA, 2015a). During this period, Thai Lion, the Indonesia's first LCC (Damuri \& Anas, 2005), aggressively led the charging with fare reductions, which forced the competitors (CAPA, 2015b).

In 2016, low-cost carrier (LCC) passengers represented 53\% of the all airline passengers in Southeast Asia, with new aircraft deliveries in 2017 expected to increase by 11\% (Camus, 2017). Furthermore, in 2016 Thai Air Asia led the market in Thailand's domestic seat capacity with $28.5 \%$. Nok Air was close behind with $20.3 \%$, Thai Lion Air with $18.7 \%$ and Thai Smile with 10.3\% (Kositchotethana, 2017a). Although Bangkok Airways had a 13\% share of domestic seat capacity, it does not consider itself a LCC and advertises itself as a 'boutique airline'.

Additionally, in 2017, Thai Airways' regional subsidiary, Thai Smile, anticipates carrying 4.5 million passengers, up from 3.2 million passengers in 2016 (Kositchotethana, 2017a).

Therefore, Thai Air Asia, Nok Air, Thai Lion, and Thai Smile, were selected for the study's focus on LCC competitiveness. Two airports were selected as well, the older and smaller, joint civilian/military airport of Don Muang (DMK), and the newer regional air hub, Suvarnabhumi (BKK), built in 2006 at a cost of US $\$ 3.0$ billion (Allett, 2005).

\subsection{Problem statement}

The Southeast Asian LCC market currently has 23 carriers with 623 aircraft carriers (December 2016). Moreover, fleet deliveries in 2017 are expected to grow 11\%, though only 5 of the total ASEAN LCCs are profitable on an $8 \%$ profit margin (DuPont, 2015). Furthermore, as competition has become fiercer, LCCs are forced to expand into new markets and international routes, but these routes are nearing saturation with over $75 \%$ having 3 or more carriers servicing them. Therefore, a qualitative and quantitative case study of the relationships of factors necessary for understanding Thai LCC competitiveness was undertaken. Using Bangkok's two primary LCC hubs, the four major LCC airlines' passengers of Thai Air Asia, Thai Lion Air, Nok Air, and Thai Smile were 
selected by use of multi-stage random sampling. The data to be gathered in this study may provide aviation and government officials the information relating to how they may improve Thai LCC competitiveness within ASEAN.

\section{Literature review}

\subsection{Service marketing mix}

According to research on the LCC Ryan Air, the service marketing mix is identified as product or service (low cost), price, place (direct marketing only), promotion (little advertising), people (staff which are young and flexible), physical evidence (aircraft), and process (first come, first served) (Wharton, 2011). These marketing mix elements were confirmed by Kotler \& Armstrong (2010); they indicated that the marketing mix is a set of controllable tactical marketing tools which includes product, price, place, and promotion, used for organizations to implement their marketing strategies. Qin (2012) expanded the number of 'Ps' to seven and indicated in his research on Thai LCCs, that the service marketing mix consisted of product, price, place, promotion, people, physical evidence, and process. In Air Asia's rise to become the leading Asian LCC, it has been observed that Air Asia penetrated the aviation industry by gaining the competitors' customers through improving the product quality and its level of service (Yashodha, 2012). This strategy was important for Air Asia because retaining existing customers is cheaper than attracting new ones, and engaging in relationship marketing activities is pertinent to retain its high lifetime value customers (Pearce \& Robinson, 2009).

Therefore, from the above and other research the following observed variables were included in the study: 1) physical evidence (PHY); 2) process (PRC); 3) personnel (EXP); 4) promotion (PRM); 5) place (PLA); price (PRI); and product services (PRO). Also, from the review of the literature and development from the above concepts, the following hypothesis was created:

H1: Service marketing mix directly and positively affects competitiveness.

H2: Service marketing mix directly and positively affects service quality.

\subsection{Passenger expectations}

In discussion concerning service quality, Lewis \& Booms (1983) stated that understanding customer expectations is a prerequisite for delivering superior service, as customers compare perceptions with expectations when judging an organization's service. Parasuraman, Berry, \& Zeithaml (1991) later defined customer expectations as the desires or wants of consumers, compared to what is being offered. Added to this in later research was the observation that that service providers must be aware of customer needs in order to fulfill expectations to achieve high customer satisfaction (Parasuraman et al., 1991).

Managing customer expectations is, therefore, an important element in creating customer satisfaction (Clow \& Beisel, 1995; Coye, 2004; Grönroos, 1994; Pitt \& Jeantrout, 1994), which should be taken into the design process. After delivering the services, service providers should monitor how well the customers' expectations have been met (Pakdil \& Aydin, 2007).

Passenger expectations is another subject for research in the environment of 'tough industry competition' (Gures et al., 2014). In the highly competitive environment, airline managers must find ways to make their services stand out amongst the others. To achieve this, managers must understand their passengers' needs, market to their educational level (Pakdil \& Aydin, 2007), and then set out to meet/exceed these needs (Nadiri et al., 2008). 
Passenger expectations are based on past experience; therefore, passengers with different experiences will have different levels of satisfaction. Passengers rely on many factors for making a decision, and there is no single standard that can evaluate their satisfaction in every situation. Positive attitudes towards product brands come from 3 main factors including confidence, centrality, and accessibility. Therefore, LCC passenger expectations are expected to have a direct and positive effect on LCC competitiveness.

From this analysis, the following observed variables were included in the study: 1) prior $(\mathrm{PRI}) ; 2$ ) consumption (CON); and 3) expectation (EXP). Also, from the review of the literature and development from the above concepts, the following hypothesis was created:

\section{H3: Passenger expectations directly and positively affect competitiveness.}

H4: Passenger expectations directly and positively affect service quality.

\subsection{Service quality}

According to Byun, Lee, \& Rye (2014), airline service quality consists of both tangible and intangible properties. This is consistent with Grönroos (1994), who proposed technical (the tangible aspects of service delivery) and functional (the expressive performance of the service) qualities, as two critical dimensions of service quality. Additionally, Curry and Gao (2012) strongly suggested that LCC service quality has become a key component at adding strategic value to an airline within their global marketplace.

This is consistent with consumer decision theory which suggests that consumers likely choose products or services based on behavioral and attitude factors, not just price (Blythe, 2013).

Shanka (2012) and Ahmed (2014) both measured Ethiopian Airlines service quality by using the SERVQUAL model, with its five dimensions, such as reliability, assurance, tangibles, empathy, and responsiveness (RATER); they indicated that safety and courtesy re the best perceived service qualities that Ethiopian Airlines renders to its customers.

In Turkey, Pakdil \& Aydin (2007) also measured airline service quality using SERVQUAL model; they found that of the variables measures, responsiveness was most important with availability being the least important. It was also noted that airlines needed to listen to the 'voice of the customer'. Another component of service quality is reliability which was defined by Baker (2014) as the ability to correctly provide the customers with services as promised without any assistance. Reliability can also be described as the ability to perform service dependably and accurately, such as punctuality, efficiency of the check-in process, and convenience and accuracy of reservations and ticketing (Kim \& Lee, 2011).

Another factor of service quality is tangibles which include the physical equipment, facilities, personnel, and communication devices. And with LCCs, tangibles have been shown to be of great importance (Lee, 2016; Kim \& Lee, 2011), especially customer responsiveness.

From the 2017, American customer satisfaction index (ACSI) reported that LCCs lead legacy airlines in passenger satisfaction; the higher scores due to lower prices was observed for the full service network carriers (FSNC). Additionally, according to ACSI's Chairman, customer satisfaction has never appeared to be a goal for airlines, when compared to other industries, as the financial return on passenger satisfaction is stated to not be much of an incentive (American customer satisfaction index, 2017). From this analysis, the following observed variables were included in the study: 1) reliability, (REL); 2) responsiveness (RES); 3) assurance (ASS); 4) empathy (EMP); and tangibles (TAN).

H5: Service quality directly and positively affects competitiveness 


\subsection{Competitiveness}

As early as 1985, Porter (1985; 2004) discussed competitive strategies and their subsequent advantages; he developed three generic strategies such as termed cost leadership (e.g. no frills airlines), differentiation (e.g. specialized products and services such as Singapore Airlines' A-380 Suites Class), and focus (e.g. specialized and remote destinations) (Baroto et al., 2012; Li \& Li, 2006). Baroto et al. (2012) discussed competitive advantage and determined that some companies such as America's Wal-Mart and Malaysia's Air Asia have succeeded with a single strategy structured on cost leadership. Cost-leadership strategies strive to supply a no-frills, high-volume, scandalized product at the most competitive price possible to passengers $(\mathrm{Li} \& \mathrm{Li}, 2008)$. Such strategies are preferred in developing countries such as Indonesia, Malaysia, India, and China which have lower labor and production costs (Aulakh et al., 2000). This was also confirmed by Acar \& Karabulak (2015) who determined that low wages were a significant factor in both LCC and Full Service Network Carriers' (FSNC) success in Turkey.

From the above research, the following observed variables were included in the study: 1) Cost Leadership (COS); 2) Differentiation (DIF); and 3) Focus (FOC).

\subsection{Conceptual model}

Model development in Figure 1 came from the SERVQUAL model for service quality, the service marketing mix, passenger expectations, and LCC competitiveness literature and theory.

FIGURE 1. CONCEPTUAL MODEL

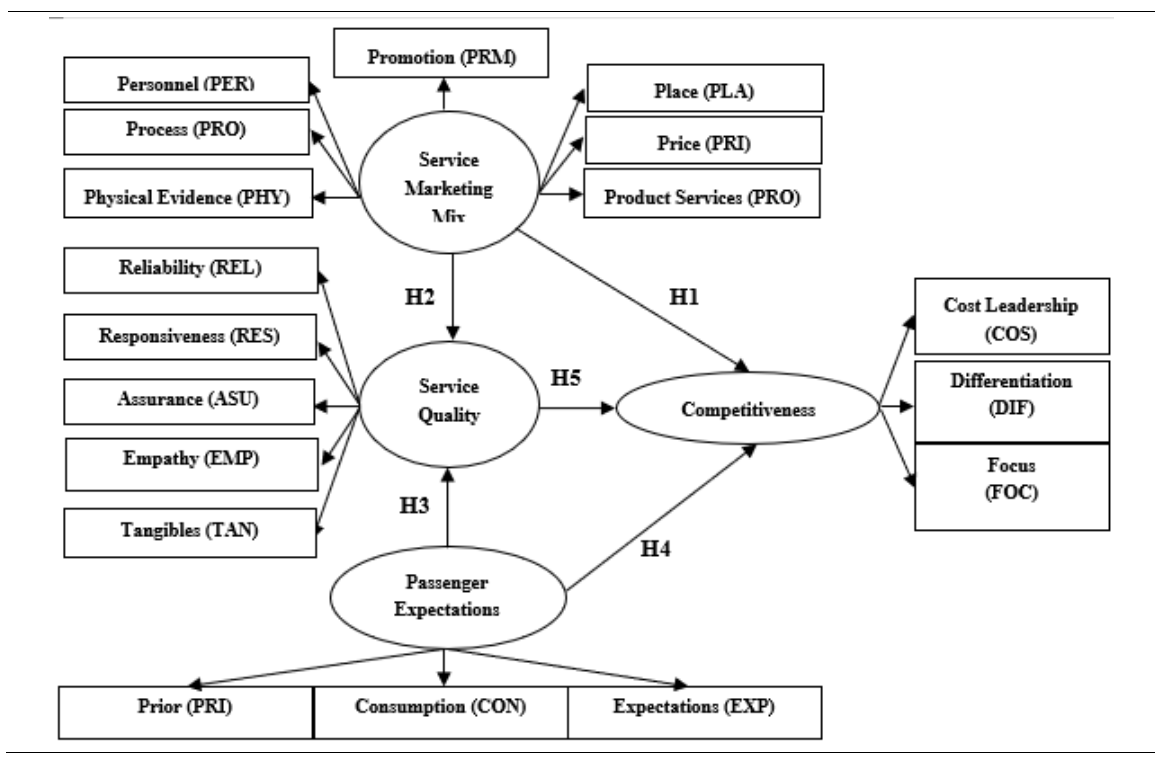

\section{Methods}

The study used quantitative, qualitative, and triangulation/mixed methods (Williams, 2007). Triangulation means using more than one method to collect data on the same topic, 
which is a way of assuring the validity of the research and capturing different dimensions of the same phenomenon.

\subsection{Population and sample}

Population size for the survey on LCC competitiveness was difficult to define clearly, therefore, multiple formulas were evaluated to determine the required size of the sample group (Cochran, 1977; Krejcie \& Morgan, 1970; Yamane, 1967). Additionally, sample size decisions are subject to the diversity in population on the variables of research and desired accuracy of results. However, the well accepted rule of thumb for sample size for studies using CFA and SEM for data analysis is a minimum of number of measurement variables * 10 (Hair Jr. et al., 2016). As the study contained 18 observed variables, 320 passengers were deemed as sufficient for the analysis (Table 1).

\section{TABLE 1. STUDY LCC POPULATION}

\begin{tabular}{lccc}
\hline Study LCCs & $\begin{array}{c}\text { Population } \\
\text { (individuals) }\end{array}$ & $\begin{array}{c}\% \text { of total } \\
\text { respondents }\end{array}$ & $\begin{array}{c}\text { Sample total } \\
\text { (individuals) }\end{array}$ \\
\hline Thai Air Asia & $22,414,088$ & $46 \%$ & 148 \\
\hline Nok Air & $15,495,199$ & $32 \%$ & 103 \\
\hline Thai Smile & $6,378,995$ & $13 \%$ & 42 \\
\hline Thai Lion Air & $4,027,567$ & $8 \%$ & 27 \\
\hline Total & $48,315,849$ & $100 \%$ & 320 \\
\hline
\end{tabular}

Source: Airlines ranking by number of passengers (2014-2015). Summary report by the Air Transport Information and Slot Coordination Division.

\subsection{Research instrument}

A seven level Likert agreement scale was used to evaluate LCC passenger responses, with '1' indicating 'strongly disagree', and '7' representing a response of 'strongly agree' (Buaphiban \& Truong, 2016). The survey also consisted of five sections containing a total of 58 items, of which nine items were concerned with the passenger's general characteristics, 21 items concerned with the service marketing mix, 15 items were concerned with service quality, four items were concerned with passenger expectations, and nine items examined LCC competitiveness.

\subsection{Instrument design process}

The LCC passenger questionnaire items were extracted after an examination of the literature's theory. Some adjustment was necessary to fit within the context of Thai culture and Asian LCCs. Questionnaire validity was determined by interviews with five individuals, and use of the Index of Item Objective Congruence (IOC) (Rovinelli \& Hambleton, 1977). Further verification came from a 30-individual test (try-out) not used in the subsequent study. The IOC used in conjunction with the expert group were tasked at evaluating the content of the survey's items. By definition, an IOC score greater or equal to 0.50 is considered acceptable, with items with an IOC less than 0.50 either being 
rejected or revised (Tavakol \& Dennick, 2011). From the five experts, questionnaire item scores ranged between 0.915 and 0.963 , which is deemed highly reliable (Kline, 2011).

\subsection{Data collection}

The process of data collection for the study began with a sample survey which had to be approved by the university management board. This was followed by applying for permission from the targeted airlines management staff to conduct the survey on their respective passengers. The airlines selected for the study were Thai Air Asia, Nok Air, Thai Lion Air, and Thai Smile (Suvarnabhumi) due to their high domestic passenger rankings (Kositchotethana, 2017a).

Over a 4-month period, from Monday to Thursday from 9AM to 3PM, two individuals were positioned at one of the four LCC check-in lines. Each week, the day in which one of the four airlines and airports was targeted was randomly rotated prior to the week's beginning. After the allocated period of four months, only 292 complete questionnaires had been collected, representing a $91.25 \%$ completion rate of the 320 targeted. Therefore, another month was added to the collection period, from which 320 complete and audited questionnaires were used for the study.

\section{Results}

\subsection{Passenger characteristics}

Table 2 shows that an overwhelming majority of Thailand's domestic air travel is done for pleasure (65\%), of which the majority is women $(54.06 \%)$. Speculation on the high number of female passengers relates to Thai culture as many Thai women avoid riding buses for long distances due to security and safety issues. The typical traveler is also young, and is 30 or younger $(50.0 \%)$. Also, it appears that flying can be a good way to meet someone as $59.38 \%$ are single. It also seems these young travelers are upwardly mobile as $69.38 \%$ have incomes above 15,000 baht a month $(\$ 435.00)$, which is the government mandated minimum starting salary for individuals graduating from university. The Thai domestic LCC passenger is also well educated, with $82.19 \%$ having a bachelor's degree or higher. It is also interesting to note that of the total respondents, $56.6 \%$ had flown on a LCC domestically 6 or more times. It might be speculated that low cost is an incentive for customer retention.

TABLE 2. PASSENGER'S CHARACTERISTICS

\begin{tabular}{llrr}
\hline Gender & Respondents & $\%$ \\
\hline & Male & 147 & 45.94 \\
\cline { 2 - 4 } & Female & 173 & 54.06 \\
\cline { 2 - 4 } & Total & 320 & 100.00 \\
\hline Age & & \\
\hline & 30 years old or younger & 160 & 50.00 \\
\cline { 2 - 4 } & $31-40$ years old & 89 & 27.81 \\
\cline { 2 - 4 } & $41-50$ years old & 52 & 16.25 \\
\cline { 2 - 4 } & T1 years old or over & 19 & 5.94 \\
\cline { 2 - 4 } & Total & 320 & 100.00 \\
\hline Status & 190 & 59.38 \\
\hline & Single & 104 & 32.50 \\
\cline { 2 - 4 } & Married & 9 & 2.81 \\
\cline { 2 - 4 } & Widowed & 17 & 5.31 \\
\cline { 2 - 4 } & Divorced & 320 & 100.00 \\
\cline { 2 - 4 } & Total & & \\
\hline
\end{tabular}




\section{TABLE 2. PASSENGER'S CHARACTERISTICS}

\begin{tabular}{|c|c|c|}
\hline \multicolumn{3}{|l|}{ Career } \\
\hline Public enterprise & 118 & 36.88 \\
\hline Government employee & 69 & 21.56 \\
\hline Entrepreneur/Business owner & 23 & 7.19 \\
\hline Other & 110 & 34.38 \\
\hline Total & 320 & 100.00 \\
\hline \multicolumn{3}{|l|}{ Income } \\
\hline Less than 15,000 Thai Baht per month & 98 & 30.63 \\
\hline $15,001-30,000$ Thai Baht per month & 119 & 37.19 \\
\hline $30,001-50,000$ Thai Baht per month & 76 & 23.75 \\
\hline 50,000 Thai Baht per month & 27 & 8.44 \\
\hline Total & 320 & 100.00 \\
\hline \multicolumn{3}{|l|}{ Education } \\
\hline Below BA/BS (e.g. vocational certificate) & 54 & 16.88 \\
\hline BA/BS degree & 188 & 58.75 \\
\hline Graduate degree & 75 & 23.44 \\
\hline Other(specialty) & 3 & 0.94 \\
\hline Total & 320 & 100.00 \\
\hline \multicolumn{3}{|l|}{ Purpose of Travel } \\
\hline Leisure travel/holiday & 208 & 65.0 \\
\hline Work & 77 & 24.1 \\
\hline To do business & 20 & 6.3 \\
\hline Other & 15 & 4.7 \\
\hline Total & 320 & 100.00 \\
\hline \multicolumn{3}{|l|}{ LCC travel experience in Thailand } \\
\hline $1-5$ times & 139 & 43.4 \\
\hline $6-10$ times & 96 & 30.0 \\
\hline $11-15$ times & 30 & 9.4 \\
\hline Over 15 times & 55 & 17.2 \\
\hline Total & 320 & 100.00 \\
\hline \multicolumn{3}{|l|}{ The LCC most frequently used } \\
\hline Thai Air Asia (Don Muang - DMK) & 148 & 46.25 \\
\hline Nok Air (Don Muang - DMK) & 103 & 32.19 \\
\hline Thai Smile (Suvarnabhumi - BKK) & 42 & 13.13 \\
\hline Thai Lion (Don Muang- DMK), & 27 & 8.44 \\
\hline Total & 320 & 100.00 \\
\hline
\end{tabular}

\subsection{Confirmatory factor analysis (CFA)}

A confirmatory factorial analysis (CFA) was carried out using structural equation modeling with LISREL (LInear Structural RELationships) 9.10 (Byrne, 1998; Diamantopoulos \& Siguaw, 2000; Jöreskog \& Sörbon, 2015) to examine the general fit of the proposed model with data and to identify the overall relationships among these constructs (Magistris \& Gracia, 2008). As suggested by Anderson \& Gerbing (1998), a 2-step analysis was conducted in which analysis of the measurement model and both sets of dependent and independent variables were conducted separately. While in the second step, analysis of the structural model of the two competing models of competitiveness was measured. The second-order CFA was, therefore, used to investigate the 4 latent variables in the conceptual framework with the 18 observed variables. 
A large number of measures exist to evaluate the empirical quality of a CFA model in terms of statistical tests, goodness of fit measures and similar criteria; each of which with its own strengths and weaknesses (van der Eijk \& Rose, 2015). Campbell \& Fiske (1959) proposed two constructs to assess the validity of a test which were convergent validity and discriminant validity. In structural equation modelling, CFA is usually used to access construct validity (Jöreskog \& Sörbom, 2015) with factor loadings or regression weight estimates of latent to observed variables having values greater than 0.50 indicating that all of the constructs conform to the construct validity test (Hair et al., 2016; Byrne, 2010). The criteria for determining the validity convergence is to have the average variance extracted (AVE) higher than 0.50 as well.

Furthermore, construct validity and reliability assessment used guidelines from scholars in Table 3. The results of the CFA shown in Table 3 indicated overall good model fit and suggested no modification to the specified factor structure. All items loaded strongly on their respective constructs, with loadings well above a threshold of 0.60 . Overall, the measurement model has a good model fit.

\section{TABLE 3. GOODNESS-OF-FIT APPRAISAL}

\begin{tabular}{|c|c|c|c|}
\hline Study LCCs & Criteria & Values & Results \\
\hline Chi-square $(\chi 2)^{1}$ & $(p>0.05)$ & 0.990 & passed \\
\hline Relative $\chi^{2}-\chi^{2} / \mathrm{df}{ }^{2}$ & $\leq 2.00$ & 0.661 & passed \\
\hline Goodness of Fit Index (GFI) & $\geq 0.90$ & 0.980 & passed \\
\hline Adjusted Goodness of Fit Index (AGFI) & $\geq 0.90$ & 0.960 & passed \\
\hline $\begin{array}{l}\text { Root Mean Square Error of Approximation } \\
(\text { RMSEA })^{3}\end{array}$ & $\leq 0.07$ & 0.000 & passed \\
\hline $\begin{array}{l}\text { Standardized Root Mean Square Residual } \\
(\text { SRMR })^{4}\end{array}$ & $\leq 0.05$ & 0.01 & passed \\
\hline Cronbach's Alpha ${ }^{5}$ & $\geq 0.80$ & $0.915-0.963$ & passed \\
\hline
\end{tabular}

\subsection{Validity}

Validity is the ability of an instrument to measure a latent construct. Three types of validity are normally required for each measurement model, which includes convergent validity (verified by computing the average variance extracted (AVE) for every construct), construct validity, and discriminant validity. To evaluate convergent validity, the AVE for each construct was evaluated against its correlation with the other constructs (Table 4). Where AVE was larger than the construct's correlation with other constructs, then convergent validity was confirmed (Gefen et al., 2000). Additionally, Cronbach's alpha and composite reliability (CR) were calculated and used to test the construct reliability, with both Cronbach's alpha values and CR values being above the suggested values (0.8) for all factors, which indicates excellent reliability (Gravetter \& Forzano, 2011). Finally, the measurement model has a good fit and the instrument has a good construct reliability and construct validity. 
TABLE 4. CFA ANALYSIS, RELIABILITY, AND CONVERGENT VALIDITY

\begin{tabular}{|c|c|c|c|c|c|c|}
\hline Latent variables & Observed variables & $\begin{array}{c}\text { Items } \\
(18)\end{array}$ & $\begin{array}{l}\text { Standardized } \\
\text { factor loading }\end{array}$ & $\begin{array}{l}\text { Cronbach's } \\
\text { alpha }\end{array}$ & AVE & $\begin{array}{c}\text { Composite } \\
\text { reliability }\end{array}$ \\
\hline Service quality & $\begin{array}{l}\text { Reliability } \\
\text { Responsiveness } \\
\text { Assurance } \\
\text { Empathy } \\
\text { Tangibles }\end{array}$ & $\begin{array}{l}\text { (REL) } \\
\text { (RES) } \\
\text { (ASS) } \\
\text { (EMP) } \\
\text { (TAN) }\end{array}$ & $\begin{array}{l}.839 \\
.915 \\
.853 \\
.874 \\
.878\end{array}$ & .928 & 0.731 & 0.931 \\
\hline $\begin{array}{l}\text { Passenger } \\
\text { expectations }\end{array}$ & $\begin{array}{l}\text { Prior } \\
\text { Consumption } \\
\text { Expectation }\end{array}$ & $\begin{array}{l}\text { (PRI) } \\
\text { (CON) } \\
\text { (EXP) }\end{array}$ & $\begin{array}{l}.927 \\
.868 \\
.861\end{array}$ & .915 & 0.785 & 0.916 \\
\hline $\begin{array}{l}\text { Service marketing } \\
\text { mix }\end{array}$ & $\begin{array}{l}\text { Physical evidence } \\
\text { Process } \\
\text { Personnel } \\
\text { Promotion } \\
\text { Place } \\
\text { Price } \\
\text { Product services }\end{array}$ & $\begin{array}{l}\text { (PHY) } \\
\text { (PRC) } \\
\text { (PEP) } \\
\text { (PRM) } \\
\text { (PLA) } \\
\text { (PRI) } \\
\text { (PRO) }\end{array}$ & $\begin{array}{l}.670 \\
.722 \\
.757 \\
.799 \\
.859 \\
.865 \\
.856\end{array}$ & .963 & 0.879 & 0.921 \\
\hline Competitiveness & $\begin{array}{l}\text { Cost leadership } \\
\text { Differentiation } \\
\text { Focus }\end{array}$ & $\begin{array}{c}\text { (COS) } \\
\text { (DIF) } \\
\text { (FOC) }\end{array}$ & $\begin{array}{l}0.854 \\
0.885 \\
0.903\end{array}$ & .935 & 0.781 & 0.914 \\
\hline
\end{tabular}

\subsection{Construct validity}

Construct validity uses both convergent and discriminant validity in combination and must be used together to establish overall validity. Technically, convergent validity can be evaluated by three tests: item reliability; composite reliability; and average variance extracted (AVE) (Chau, 1997) (Table 5). The first measure, item reliability is indicated if items have significant factor loadings of 0.50 or above. The second measure, composite reliability, is assessed based on the criteria that the indicator's estimated pattern coefficient is significant on its underlying factor, which should have a threshold value for construct reliability at 0.70 or higher. Table 2 shows the composite reliability (CR) was higher than 0.60 , with all AVE values higher than 0.50 , and all $\mathrm{R}^{2}$ values classified as 'substantial' in Table 6 (Hair et al. 2016).

\section{TABLE 5. CORRELATION COEFFICIENTS BETWEEN LATENT VARIALBES (UNDER THE DIAGONAL), CONSTRUCT RELIABILITY $(\rho C)$, AND THE AVERAGE VARIANCE EXTRACTED (AVE)}

\begin{tabular}{lcccc}
\hline Latent variables & Competitiveness & $\begin{array}{c}\text { Service } \\
\text { quality }\end{array}$ & $\begin{array}{c}\text { Service } \\
\text { marketing } \\
\text { mix }\end{array}$ & $\begin{array}{c}\text { Passenger } \\
\text { expectations }\end{array}$ \\
\hline Competitiveness & 1.000 & & & \\
\hline Service quality & 0.827 & 1.000 & & \\
\hline $\begin{array}{l}\text { Service marketing } \\
\text { mix }\end{array}$ & 0.829 & 0.897 & 1.000 & \\
\hline $\begin{array}{l}\text { Passenger } \\
\text { expectations }\end{array}$ & 0.880 & 0.878 & 0.866 & 1.000 \\
\hline
\end{tabular}




\section{TABLE 5. CORRELATION COEFFICIENTS BETWEEN LATENT VARIALBES \\ (UNDER THE DIAGONAL), CONSTRUCT RELIABILITY $(\rho C)$, AND THE \\ AVERAGE VARIANCE EXTRACTED (AVE)}

\begin{tabular}{lcccc}
\hline Latent variables & Competitiveness & $\begin{array}{c}\text { Service } \\
\text { quality }\end{array}$ & $\begin{array}{c}\text { Service } \\
\text { marketing } \\
\text { mix }\end{array}$ & $\begin{array}{c}\text { Passenger } \\
\text { expectations }\end{array}$ \\
\hline $\begin{array}{l}\rho C \text { (construct } \\
\text { reliability) }\end{array}$ & 0.914 & 0.931 & 0.921 & 0.916 \\
\hline$\rho \mathrm{V}(\mathrm{AVE})$ & 0.781 & 0.731 & 0.879 & 0.785 \\
\hline$\sqrt{\mathrm{AVE}}$ & 0.884 & 0.855 & 0.937 & 0.886 \\
\hline
\end{tabular}

Note. Average variance extracted is shown on the diagonal of the matrix. Square of inter-

construct correlation is shown off the diagonal.

\subsection{The direct effect (DE), indirect effect (IE), and total effects (TE)}

Table 6 shows the DE, IE, and TE effects of each construct.

TABLE 6. STANDARD COEFFICIENTS OF INFLUENCE

\begin{tabular}{|c|c|c|c|c|c|}
\hline \multirow{2}{*}{$\begin{array}{l}\text { Dependent } \\
\text { variables }\end{array}$} & \multicolumn{5}{|c|}{ Independents } \\
\hline & & $\mathrm{R}^{2}$ & $\begin{array}{c}\text { Passenger } \\
\text { expectations }\end{array}$ & $\begin{array}{c}\text { Service } \\
\text { marketing } \\
\text { mix }\end{array}$ & $\begin{array}{l}\text { Service } \\
\text { quality }\end{array}$ \\
\hline \multirow[t]{3}{*}{ Competitiveness } & $\mathrm{DE}$ & \multirow[t]{3}{*}{0.79} & $0.60^{* *}$ & $0.21^{*}$ & 0.11 \\
\hline & $\mathrm{IE}$ & & 0.05 & 0.06 & - \\
\hline & TE & & $0.65^{\star *}$ & $0.27^{* *}$ & 0.11 \\
\hline \multirow[t]{3}{*}{ Service quality } & $\mathrm{DE}$ & \multirow[t]{3}{*}{0.85} & $0.40^{* *}$ & $0.55^{\star *}$ & - \\
\hline & $\mathrm{IE}$ & & - & - & - \\
\hline & TE & & $0.40^{* *}$ & $0.55^{\star \star}$ & - \\
\hline
\end{tabular}

Note. ${ }^{*}$ - significance $<0.05,{ }^{* *}$ - significance $<0.01$

\subsection{Structural equation model (SEM)}

The SEM results (Figure 2) from the analysis on service marketing mix, passenger expectations, service quality, and LCC competitiveness showed that all models met the required criteria as the chi-square index was not statistically significant at 58.82 , the $p$ value was $=0.99$, RMSEA $=0.00$, GFI $=0.98$, AGFI $=0.96$, and SRMR $=0.01$. All causal factors in the model had a positive influence on the LCC competitiveness, which can explain $79 \%$ of variance in competitiveness of low cost airlines in Thailand $\left(\mathrm{R}^{2}\right)$. The variables passenger expectations, service quality mix, and service quality had a total value of $0.65,0.27$, and 0.11 , respectively. Results of hypotheses testing are shown in Table 7. 


\section{FIGURE 1. FINAL MODEL}

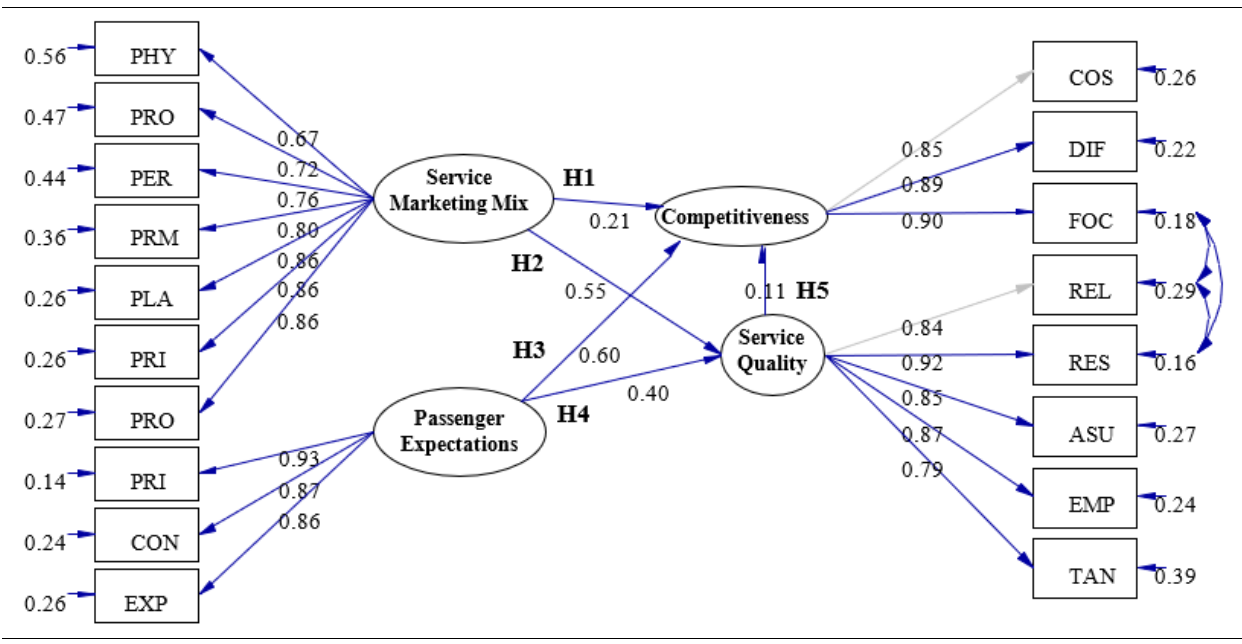

Note. Chi-Square $=58.82, \mathrm{df}=89, \mathrm{p}$ value $=0.99, \mathrm{RMSEA}=0.000$.

Hypotheses testing results from the use of LISREL 9.1 are summarized in Table 7, which shows that $\mathrm{H} 1$ is supported with a standardized regression coefficient of 0.21 at a $p$ value of less than 0.05, indicating that the service marketing mix of LCCs has a positive impact on LCC competitiveness. This was consistent with studies on the LCC Ryan Air, which identified the airline service marketing mix as focused on a cost leadership strategy, airport location outside major hubs, direct marketing only, little advertising, staff which are young and flexible, one type of aircraft consisting of 370 Boeing 737-800s, and Ryan's first come, first served policy (Diaconu, 2012; Wharton, 2011).

\section{TABLE 7. HYPOTHESES TESTING}

\begin{tabular}{lcccc}
\hline \multicolumn{1}{c}{ Hypotheses } & Coef. & t-value & $p$ value & Results \\
\hline $\begin{array}{l}\text { H1: Service marketing mix directly and } \\
\text { positively affects competitiveness }\end{array}$ & 0.21 & 2.04 & $<0.05^{*}$ & supported \\
\hline $\begin{array}{l}\text { H2: Service marketing mix directly and } \\
\text { positively affects service quality }\end{array}$ & 0.55 & 7.21 & $<0.01^{* *}$ & supported \\
\hline $\begin{array}{l}\text { H3: Passenger expectations directly and } \\
\text { positively affects competitiveness }\end{array}$ & 0.60 & 6.33 & $<0.01^{* *}$ & supported \\
\hline $\begin{array}{l}\text { H4: Passenger expectations directly and } \\
\text { positively affects service quality }\end{array}$ & 0.40 & 5.56 & $<0.01^{* *}$ & supported \\
\hline $\begin{array}{l}\text { H5: Service quality directly and positively } \\
\text { affects competitiveness }\end{array}$ & 0.11 & 1.12 & $>0.05$ & rejected \\
\hline $\begin{array}{l}\text { Note. }{ }^{* *} \text { - Relationships are significant at the }<0.01 \text { level, }{ }^{*} \text { - Relationships are significant at the }<0.05 \text { level, } \text { Coef. - } \\
\text { standardized regression coefficients. }\end{array}$ & & & &
\end{tabular}

Service marketing mix once again showed its strength and importance in $\mathrm{H} 2$, and its effect on LCC competitiveness with a standardized regression coefficient of 0.55 , having a $p$ value of less than 0.01 . It is the service marketing mix which was determined to have the most significant effect on Thai LCC competitiveness which was consistent with earlier studies which stated that the service marketing mix and service quality are the most 
important factors that affect the low-cost airline passenger satisfaction and loyalty in Thailand (Qin, 2012), and thus the carrier's competitiveness.

H3 in which passenger expectations was shown to have positively affected LCC competitiveness had a standardized regression coefficient was 0.60 , with a $p$ value of less than 0.01 . H4 was also supported which showed that passenger expectations directly $(0.40)$ and positively $(\phi<0.01)$ affects competitiveness.

From the research, it was also determined that staff responsiveness (.915) and LCC assurance (.853) were also key elements, which was consistent with an airline passenger study in Hong Kong which determined that passengers consistently rank assurance, which includes safety and security, as the most important service dimension (Gilbert \& Wong, 2003). Also, Hussain et al. (2015) used the SERVQUAL model to determine that airline service quality, perceived value, and brand image, have a positive and significant impact on customer satisfaction, which can in turn lead to brand loyalty. This agrees with Air Asia's yearly financial report (Air Asia Annual Report, 2015), which stated that in the case of Indonesia Air Asia, maintaining a high level of service quality and continuously enamoring its guests with warm hospitality, helped it gain marketplace recognition. The cultural dimension has been shown time again to have an effect on passenger expectations in Asian aviation (Gilbert \& Wong, 2003).

Finally, results from the research did not support $\mathrm{H} 5$ ( $\not>0.05)$, and the relationship between service quality and LCC competitiveness, which is supported by research from Chan (2014) which indicated that LCC passengers are willing to revise their service expectations downward because of the price (Chan, 2014; Kuosuwan, 2015). Thus, the important thing for LCCs is that they determine the expectations of their passengers and meet them (Buaphiban \& Truong, 2016).

\section{Discussion}

Due to multiple factors including aviation deregulation, open skies policies, a more affluent consumer market, and a new generation of entrepreneurial leaders, ASEAN LCCs have been a runaway success story (Air Asia Annual Report, 2011, 2015; Baker, 2013, 2014; Camus, 2017; Damuri \& Anas, 2005; Kim \& Lee, 2011; Smith and Cox, 2008). Presently, 23 LCCs with more than 623 aircraft are flying the low-cost ASEAN skies (CAPA, 2016a), with Bangkok, Thailand a major LCC hub.

The liberalization of ASEAN's aviation sector will be a major catalyst for the region's 10nation economic growth by 2030, while today LLCs account for about $60 \%$ of the total aviation market (DuPont, 2015). In some markets such as the Philippines, this percentage rises to $70 \%$ - 80\% (Ocampo, 2017). Growth however has led to more fierce competition and lower ticket prices amongst LCCs (CAPA, 2015b), with carriers looking for new routes into new markets to offset passenger losses to competitors, thus depressing yields and cutting into their profitability (Kositchotethana, 2017c). It appears that further regional and Asian expansion is in many Thai LCCs game plan for profitability and possible survivability.

In Turkey, it was determined that for LCCs to offer competitively low fares and be profitable, LCCs must be able to operate at substantially lower unit costs than FSNC airlines (Acar \& Karabulak, 2015). LCC cost advantages stem from the carrier's simple product features and simplified operations, as well as low staff wages being a significant factor in both LCC and FSNC success in Turkey.

LCC competitiveness has also been determined to come from other factors such as higher seating density and higher daily aircraft utilization, as well as the use of less congested suburban and rural airports (European Parliament, 2007) which often allows quicker turnaround times and less taxing times. As one might expect, there is also a significant saving in airport 
charges, that is, aircraft landing fees and passenger related charges is different (Acar \& Karabulak, 2015).

Another recent innovation in creating LCC competitiveness is the use of cabin interiors as flying billboards. Although exterior adverting has been around for some time (Air Asia started it in 2005), decking interiors out with brightly colored cosmetic ads everywhere in Chinese seem to be a coming trend for LCCs in Asia (Sawai, 2017).

In Thailand, use of underutilized airports has taken on a larger dimension, as to relieve critical airline congestion and serve as a new economic and infrastructure hub, the Vietnam era, joint Thai Navy/civilian airfield of U-Tapao is being upgraded to serve as the hub for Thailand 4.0's new Eastern Economic Corridor (ECC) (Jones \& Pimdee, 2017). The US\$5.7 billion investment plan includes runway expansion and new aircraft hangars and maintenance facilities, which is stated to be the starting place for Thailand's push to become Asia's next major aviation hub (Bellamy, 2017). In 2014, U-Tapao was transitioned into a joint civil-military airport, which caused the number of annual passengers using the airport to jump from 168,000 in 2014, to 750,000 in 2016 , to a projected 1.3 million in 2017 . To support this, the new US $\$ 480$ million, 20,000 square meter terminal two is expected to be completed in August 2017. Already Thai Air Asia and Thai Lion Air are proposing using U-Tapao as their new hubs into new international markets such as Macau, Nanning, Nanchang, and Kuala Lumpur (Thai Air Asia), and Chengdu and Chongqing (Thai Lion Air) (Citrinot, 2017). Once again, competition is fierce with route expansion into China appearing to be a major strategy for ASEAN LCCs operating from Thailand, which are competing for the expected 9.8 million Chinese tourists projected in 2017 (Janthong, 2017).

Also, another factor in LCC competitiveness is their relatively newer aircraft of a single type (Cederholm, 2014). An example of both can be found in Ryan Air's fleet of 370 Boeing 737 800s (Diaconu, 2012; Wharton, 2011), which helps reduce training and maintenance costs., while also reducing fuel costs as a younger fleet is more fuel efficient. This strategy is another way to achieve competitiveness by reducing direct operating cost, where cost savings can also be realized by the outsourcing of maintenance requirements, and in some cases even line maintenance.

Concerning passenger expectations, LCCs need to accurately identify the expectations of the passengers they offer services to, as most LCCs operate on the same routes with similar prices and capacities, retaining passenger attraction and loyalty seems to have become a critical requirement for companies to gain a competitive advantage, as customer satisfaction is what guarantees the future of airlines (Qin, 2012). This is consistent with Indonesia Air Asia, where it was stated that by maintaining a high level of service quality and continuously enamoring its guests with warm hospitality, the LCC was able to gain marketplace recognition (Air Asia Annual Report, 2015).

\section{Conclusion}

Even if astonishing growth rates ebb lower as markets grow more mature, Southeast Asian carriers account for $15 \%$ of the global aircraft orders (1,065 airplanes) (CAPA, 2016b; DuPont, 2015). This ever increasing number of LCCs and their aircraft fleets reflects the growing popularity of budget airlines due to offering lower fares than full-service carriers (by a margin of about 30\%), their growing networks, additional frequencies, and heavy sales promotions (Kositchotethana, 2016). In Thailand, LCCs in 2016 represented 44.9\% of all passengers through Thailand's 6 major airports, which represented 54.7 million passengers out of a total of 122 million air travelers (Kositchotethana, 2017). Although these numbers are impressive, Asian LCCs are operating at profit margins of only $8 \%$, which is significantly smaller than those of their western nation rivals, which operate at 15\% (Whitley, 2016).

Also, ASEAN and Asia aviation in general are already among the world's most competitive markets, with $75 \%$ of the routes operated by more than three carriers. These 
factors have therefore contributed to the statistic that there were only five profitable LCCs in the region out of 24 carriers in 2015 (DuPont, 2015). Competitiveness therefore has become the watchword for survivability, and although the future is bright for LCCs, there will be dark clouds for those that don't maintain extreme vigilance on their service marketing mix, service quality, and the identification of their passengers' expectations.

\section{References}

Acar, A. Z., \& Karabulak, S. (2015). Competition between full service network carriers and lowcost carriers in Turkish airline market. Procedia - Social and Behavioral Sciences, 207, 642-651. http://dx.doi.org/10.1016/j.sbspro.2015.10.134

Air Asia Annual Report. (2011). Enriching Asean and beyond: Annual report 2011. Retrieved October 19, 2017, from http://tinyurl.com/lp33jow

Air Asia Annual Report. (2015). Discover more with Air Asia: Annual report 2015. Retrieved October 19, 2017, from http://tinyurl.com/mwnbn3d

Allett, T. (2005). The golden land: In 2006, Bangkok's Don Muang Airport will be replaced by a new state-of-the-art facility named Suvarnabhumi - The golden land. Airports International, 38(8), 14-15. Retrieved October 19, 2017, from http://tinyurl.com/hl73qbz

Aulakh, P. S. (2000). Export strategies and performance of firms from emerging economies: Evidence from Brazil, Chile and Mexico. Academy of Management Journal, 43(3), 342-361.

Ahmed, A. (2014). Measuring service quality at Ethiopian Airlines (Unpublished master's thesis). St. Mary's University, Addis Ababa. Retrieved October 19, 2017, from http://tinyurl.com/ meducem

American customer satisfaction index. (2017). Benchmarks by industry. Retrieved October 19, 2017, from http://tinyurl.com/zc582ga

American customer satisfaction index. (2017). ACSI: Low-Cost Camiers Lead Legay Airlines for Passenger Satisfaction. Retrieved October 19, 2017, from http://tinyurl.com/lakk9ye

Amiruddin, N. H. (2013). Price, service quality and customer loyalty: A case study of Air Asia. South East Asia Journal of Contemporary Business, Economics and Law, 2(1). Retrieved October 19, 2017, from http://tinyurl.com/lhohoae

Anderson, J. C., \& Gerbing, D. W. (1998). Structural equation modeling in practice: A review and recommended two-step approach. Psychological Bulletin, 103(5), 204-215. https://doi.org/10.1037//0033-2909.103.3.411_

ASEAN Briefing. (2015). ASEAN Open Skies Policy to be implemented in 2015. Retrieved October 19, 2017, from http:// tinyurl.com/n7hrl7w

Asiegbu, I. F., Igwe, P., \& Akekue-Alex, N. (2012). Physical evidence and marketing performance of commercial airlines in Nigeria. American International Journal of Contemporary Research, 2(12). Retrieved October 19, 2017, from http://tinyurl.com/n7jmrdg

Baker, D. (2013). Service quality and customer satisfaction in the airline industry: A comparison between legacy airlines and low-cost airlines. American Journal of Transport Tourism Research, 2(1), 67-77. http://dx.doi.org/10.11634/216837861302317

Baker, D. (2014). Low-cost airlines management model and customer satisfaction. International Journal of Economics, Commerce, and Management, 2(9), 1-17. Retrieved October 19, 2017, from http://tinyurl.com/jxg2ymb

Baroto, M., B., Abdullah, M. M. B., \& Wan, H. L. (2012). Hybrid strategy: A new strategy for competitive advantage. International Journal of Business and Management, 7(20). 
Bellamy, W. (2017). Thailand wants to become Asia's next aviation hub. Retrieved October 19, 2017, from http://tinyurl.com/n2eshoj

Blythe, J. (2013). Consumer behavior. Thousand Oaks, CA: Sage Publications.

Buaphiban, T., \& Truong, D. (2016). Evaluation of passengers' buying behaviors toward low cost carriers in Southeast Asia. Journal of Air Transport Management, 59, 124-133.

Byrne, B. M. (1998). Structural equation modeling with LISREL, PRELIS and SIMPLIS: Basic concepts, applications and programming. Mahwah, NJ: Lawrence Erlbaum Associates.

Byrne, B. M. (2010). Structural equation modeling with AMOS: Basic concepts, applications, and programming ( $2^{\text {nd }}$ ed.). New York, NY: Routledge. Retrieved October 19, 2017, from http://tinyurl.com/ ze 7 ze $7 d$

Byun, H., Lee, B., \& Rye, J. (2014). A comparative study on evaluating the service quality attributes based on Kano Model: A case of low-cost carrier and fullof Conferences, 12. https://doi.org/10.1051/shsconf/20141201017

Campbell, D. T., \& Fiske, D. W. (1959). Convergent and discriminant validation by the multitraitmultimethod matrix. Psychological Bulletin, 56(2), 81-105. https://doi.org/10.4135/9781412961288.n79

Camus, M. R. (2017, January 26). Budget airlines seek to boost aircraft haul. Philippine Daily Inquirer. Retrieved from http://tinyurl.com/lqydknn

CAPA. (2015a, March). Thai Airways embarks on major network and fleet restructuring but longterm challenges remain. Centre for Aviation. Retrieved October 19, 2017, from http:/ / tinyurl.com/j98frh8

CAPA. (2015b, April). Competition in Thailand's domestic LCC sector intensifies further as Thai Lion, Nok \& Air Asia expand. Centre for Aviation. Retrieved from http://tinyurl.com /hlwsxbq

CAPA. (2016a, January). Southeast Asia's low cost airline fleet expands by 13\% in 2015 as short haul capacity growth. Centre for Aviation. Retrieved October 19, 2017, from http://tinyurl.com/zuvfk4f

CAPA. (2016b, June). LCC models in Southeast Asia evolve as growth slows, though outlook remains bright. Retrieved October 19, 2017, from http://tinyurl.com/n6cfazb

CAPA. (2017, January). Southeast Asia LCC fleet expansion to reaccelerate in 2017 after rare single digit growth in 2016. Retrieved October 19, 2017, from http://tinyurl.com/18qmoxq

Cederholm, T. (2014). Low cost carrier strategies to maintain competitive advantage. Retrieved October 19, 2017, from http://tinyurl.com/knsugkm

Chau, P. Y. K. (1997). Reexamining a model for evaluating information center success using a structural equation modeling approach. Decision Sciences. 28 (2), 309-334.

Citrinot, L. (2017, April 11). Pattaya U-Tapao Airport to become "Bangkok third airport"? Asean travel. Retrieved October 19, 2017, from http://tinyurl.com/n5vor3e

Clow, K. E., \& Beisel, J. L. (1995). Managing consumer expectations of low-margin, high-volume services. Journal of Services Marketing, 9(1), 33-46.

Corera, G. (1998). Thailand: The crisis starts. BBC. Retrieved October 19, 2017, from http://tinyurl.com/kqkv3yq

Coye, R. W. (2004). Managing customer expectations in the service encounter. International Journal of Services Industry Management, 15(1), 54-71. http://dx.doi.org/10.1108/09564230410523330 
Chan, J. K. L. (2014). Understanding the meaning of low airfare and satisfaction among leisure air travelers using Malaysian low-cost airlines. Journal of Vacation Marketing, 20(3), 211-223. https://doi.org/10.1177/1356766713519635

Chang, Y. W., \& Chang, Y. H. (2010). Does service recovery affect satisfaction and customer loyalty? An empirical study of airline services. Journal of Air Transport Management, 16(6), 340342. https://doi.org/10.1016/j.jairtraman.2010.05.001

Cochran, W. G. (1977). Sampling techniques (3rd ed.). New York: John Wiley \& Sons. Retrieved October 19, 2017, from http://tinyurl.com/173eqvp

Curry, N., \& Gao, Y. (2012). Low-cost airlines - A new customer relationship? An analysis of service quality, service satisfaction, and customer loyalty in a low-cost setting. Services Marketing Quarterly, 33(2), 104-118. http://dx.doi.org/10.1080/15332969.2012.662457

Damuri, Y. R., \& Anas, T. (2005). Strategic directions for ASEAN airlines in a globalizing world: The emergence of low cost carriers in South East Asia. REPSF Project No. 04/008. Retrieved October 19, 2017, from http://tinyurl.com/jc7846f

de Jager, J. W., \& van Zyl, D. (2013). Airline service quality in South Africa and Malaysia-An international customer expectations approach. Journal of Economics and Behavioral Studies, 5(11), 752-761. Retrieved October 19, 2017, from http://tinyurl.com/kbmmqyp

Diamantopoulos, A., \& Siguaw, J. A. (2000). Introducing LISREL. London, UK: Sage Publications.

Diaconu, L. (2012). The evolution of the European low-cost airlines' business models. Ryanair case study. Procedia - Social and Behavioral Sciences, 62, 342-346.

Drummon, G. A., \& Ensor, J. (2001). Strategic marketing: Planning and control. Singapore: Wiley \& Sons. Inc.

DuPont, G. (2015). South East Asia aviation: What you need to know. New Airport Insider. Retrieved October 19, 2017, from http://tinyurl.com/19dw6vf

Edwards, J. E. (2011). Key characteristics and attitudes of airline passengers, with particular emphasis upon the low-cost sector: Implications for pre-trip decision-making and airline choice. (unpublished doctoral dissertation). University of Westminster, UK. Retrieved October 19, 2017, from http://tinyurl.com/mr2rc5x

El-Ansary, A. (2006). Market strategy: Taxonomy and frameworks. European Business Review, 18(4), 266-293. https://doi.org/10.1108/09555340610677499

European Parliament. (2007). The consequences of the growing European low-cost airline sector. IP/B/TRAN/IC/2006-185, PE 397.234. Retrieved October 19, 2017, from http://tinyurl.com/k3xk6sz

Gefen, D, Straub, D, \& Boudreau, M-C. (2000). Structural equation modeling and regression: guidelines for research practice. Communications of the AIS, 4, 1-78.

Ghobadian, A., Speller, S., \& Jones, M. (1994). Service quality: Concepts and models. International Journal of Quality \& Reliability Management, 11, 43-66.

Gilbert, D., \& Wong, R. K. C. (2003). Passenger expectations and airline services: A Hong Kong based study. Tourism Management, 24(5), 519-532. https://doi.org/10.1016/S02615177(03)00002-5

Gravetter, F., \& Forzano, L. (2011). Research methods for the behavioral sciences. Mason, OH: Cengage Learning.

Grönroos, C. (1994). From scientific management to service management: A management perspective for the age of service competition. International Journal of Services Industry Management, 5, 5-20. http://dx.doi.org/10.1108/09564239410051885 
Grosso, M. G., \& Shepherd, B. (2010). Air cargo transport in APEC: Regulation and effects on merchandise trade. OECD Trade and Agriculture Directorate. Retrieved October 19, 2017, from http://tinyurl.com/m6kyr4f

Gures, N., Arslan, S., \& Tun, S. Y. (2014). Customer expectation, satisfaction and loyalty relation in Turkish airline industry. International Journal of Marketing Studies, 6(1). https://doi.org/10.5539/ijms.v6n1p66

Hair, J. F. Jr., Hult, G. T. M., Ringle, C., \& Sarstedt, M. (2016). A primer on partial least squares structural equation modeling (PLS-SEM). ( $3^{\text {rd }}$ ed.). Thousand Oaks, CA, USA: Sage.

Hu, L. T., \& Bentler, P. M. (1999). Cutoff criteria for fit indexes in covariance structure analysis: Conventional criteria versus new alternatives. Structural Equation Modeling, 6(1), 1-55. http://dx.doi.org/10.1080/10705519909540118

Hussain, R., Al Nasser, A., \& Hussain, Y. K. (2015). Service quality and customer satisfaction of a UAE-based airline: An empirical investigation. Journal of Air Transport Management, 42, 167175. https://doi.org/10.1016/j.jairtraman.2014.10.001

Ishutkina, M. A., \&Hansman, R. J. (2009). Analysis of the Interaction between air transportation and economic activity: $A$ worldwide perspective. (Unpublished doctoral dissertation). Massachusetts Institute of Technology, Boston. Retrieved October 19, 2017, from http://tinyurl.com/kyd8pk8

Janthong, P. (2017, January 5). Can tourism recover? Bangkok Post. Retrieved October 19, 2017, from http://tinyurl.com/mawhxnn

Jones, C., \& Pimdee, P. (2017). Innovative ideas: Thailand 4.0 and the fourth industrial revolution. Asian International Journal of Social Sciences, 17(1), 4-35. Retrieved October 19, 2017, from http://tinyurl.com/lw8a5cn

Jöreskog, K. G., \& Sörbom, D. (2015). LISREL 9.20 for Windows. Skokie, IL:

Scientific Software International, Inc.

Kim, Y. K., \& Lee, H. R. (2011). Customer satisfaction using low cost carriers. Tourism Management, 32, 235-243. Retrieved October 19, 2017, from http://tinyurl.com/h8725ma

Kline, R. B. (2011). Principles and practice of structural equation modelling ( $3^{\text {rd }}$ ed.). New York, NY: The Guilford Press.

Kotler, P., \& Armstrong, G. (2010). Principles of Marketing (13th ed.). Boston, MA: Pearson Education, Inc.

Krejcie, R. V., \& Morgan, D. W. (1970). Determining sample size for research activities. Educational and Psychological Measurement, 30, 607-610.

Lewis, R. C., \& Booms, B. H. (1983). The marketing aspects of service quality. In L.L. Berry, G.L. Shostack, and G. Upah (Eds.), Emerging Perspectives on Services Marketing, Chicago: American Marketing Association (pp. 99-107).

Li, C., B., \& Li, J. J. (2006). Achieving superior financial performance in China: Differentiation, cost leadership, or both? Journal of International Marketing, 16(3). Retrieved October 19, 2017, from http://tinyurl.com/19zdru9

Kositchotethana, B. (2016, November 18). LCCs strengthening hold on Thai airline industry. Bangkok Post. Retrieved October 19, 2017, from http://tinyurl.com/h6m4sbf

Kositchotethana, B. (2017a, February 22). TAA widens lead over budget rivals. Bangkok Post. Retrieved October 19, 2017, from http://tinyurl.com/n2xehbs

Kositchotethana, B.. (2017b, February 20). Budget carrier's passenger traffic continues to soar. Bangkok Post. Retrieved October 19, 2017, from http://tinyurl.com/len4qpe 
Kositchotethana, B.. (2017c, May 12). Crowded skies leave airlines bustling. Bangkok Post. Retrieved October 19, 2017, from http://tinyurl.com/mvvelau

Kuosuwan, B. (2015). Market factors influencing the decision to patronage low cost carriers. Procedia - Social and Behavioral Sciences, 197, 2097-2102. https://doi.org/10.1016/j.sbspro.2015.07.328

Magistris, T. D., \& Azucena, G. (2008). The decision to buy organic food products in Southern Italy. British Food Journal, 110(9), 929-847.

Martin, W. B. (1995). Quality customer service for front line staff. Menlo Park, CA: Crisp Publication, Inc.

Nadiri, H., Hussain, K., Ekiz, E. H., \& Erdoğan, Ş. (2008) .An investigation on the factors influencing passengers' loyalty in the North Cyprus national airline. The TQM Journal, (3)20, 265-280. http://dx.doi.org/10.1108/17542730810867272

Ocampo, R. (2017). Navigating through crowded skies. TTG Asia. Retrieved October 19, 2017, from http://tinyurl.com/k57f6km

Pakdil, F., \& Aydın, O. (2007). Expectations and perceptions in airline services: An analysis using weighted SERVQUAL scores. Journal of Air Transport Management, 13(4), 229-237. http://dx.doi.org/10.1016/j.jairtraman.2007.04.001

Parasuraman, A., Berry, L. L., \& Zeithaml, V. A. (1991). Understanding customer expectations of service. Sloan Management Review, 32(3), 39-48. Retrieved October 19, 2017, from http://tinyurl.com/mtyvq4e

Pearce, J. A., \& Robinson, R. B. (2009). Formulation, implementation \& control of competitive strategy (11 ${ }^{\text {th }}$ ed.). International Edition: McGraw-Hill.

Pitt, L. F., \& Jeantrout, B. (1994). Management of customer expectations in service firms: A study and a checklist. Service Industries Journal, 14(2), 170-190.

http://dx.doi.org/10.1080/02642069400000021

Porter, M. E. (1985). Creating and sustaining superior performance. New York, NY: Free Press.

Porter, M. E. (2004). Competitive Advantage: Creating and Sustaining Superior Performance. New York, NY: Free Press.

Qin, Z. (2012). The factors influencing low-cost airline passenger satisfaction and loyalty in Bangkok, Thailand. Graduate thesis. University of the Thai Chamber of Commerce, Bangkok, Thailand. Retrieved October 19, 2017, from http://tinyurl.com/k9nggpz

Rovinelli, R. J., \& Hambleton, R. K. (1977). On the use of content specialists in the assessment of criterion-referenced test item validity. Dutch Journal of Educational Research, 2, 49-60.

Sawai, S. (2017). Advertising boost drops airfare at budget carrier. Nikkei Asian Review Retrieved October 19, 2017, from http://tinyurl.com/kq58b5k

Schiffman, L. G., \& Kanuk, L. L. (2007). Consumer Behavior (9th ed.). Englewood Cliffs, NJ: Prentice-Hall.

Shanka, M. S. (2012). Measuring service quality in Ethiopian Airlines. Journal of Educational and Social Research, 2(9). http://doi.org/10.5901/jesr.2012.v2n9p173

Smith Jr., F. L., \& Cox, B. (2008). Airline deregulation. The concise encyclopedia of economics. Library of Economics and Liberty.

Sobie, B. (2008). Mountain climbing. Airline Business, 255. Retrieved October 19， 2017, from http://tinyurl.com/k25wlwf

Tavakol, M., \& Dennick, R. (2011). Making sense of Cronbach's alpha. International. Journal of Medical Education, 2, 53-55. 
http://doi.org/10.5116/ijme.4dfb.8dfd

Tham, S. Y. (2008). ASEAN open skies and the implications for airport

development strategy in Malaysia. ADB Institute. Retrieved October 19, 2017, from http://tinyurl.com/j3w7q5b

van der Eijk, C., \& Rose, J. (2015). Risky business: Factor analysis of survey data - Assessing the probability of incorrect dimensionalisation. PloS One, 10(3).

https://doi.org/10.1371/journal.pone.0118900

Wharton. (2011). Ryanair marketing mix. Retrieved October 19, 2017, from http://tinyurl.com/kmjet8f

Whitley, A. (2016, December). Asia's largest airlines may soon cut passenger perks. Bloomberg. Retrieved October 19, 2017, from http://tinyurl.com/zunne7k

Williams, C. (2007). Research methods. Journal of Business \& Economic Research, 5(3), 65-72. Retrieved October 19, 2017, from http:// tinyurl.com/lcq6joj

Yamane, T. (1967). Statistics, an introductory analysis (2nd ed.). New York, NY: Harper and Row.

Yashodha, Y. (2012). Air Asia Berhad: Strategic analysis of a leading low cost carrier in the Asian region. Elixir Mgmt. Arts, 51, 11164-11171. Retrieved October 19, 2017, from http://tinyurl.com/k4hs6f5 